\title{
ANALYSIS OF DOWNTIME IN A TYPICAL NIGERIAN MULTINATIONAL BOTTLING COMPANY
}

\author{
ABAFI JOEL ${ }^{1}$, OKE ADEKOLA ${ }^{* 1}$ \\ ${ }^{I}$ Department of Mechanical Engineering, Obafemi Awolowo University, Ile-Ife, Osun State, \\ Nigeria
}

\begin{abstract}
Failure data were extracted from the report book of the case study company. These data were stratified and analysed.Data stratification was pivotal in the separation of failure data into smaller and more defined form based on a predetermined set of criteria. Filler system was found to have the highest percentage failure occurrences; hence a standby filler system became the best option. The study concluded that, although in a production/manufacturing system, downtime is inevitable but it can be limited to the planned downtime with respect to the typical Nigerian multinational bottling company.
\end{abstract}

Keywords: downtime, maintenance, reliability, failure data, machine

\section{INTRODUCTION}

The goal of every manufacturing and production organisation is to reduce production losses in terms of waste and maintenance cost for the increase of overall equipment efficiency (OEE). Downtime is a critical subject in manufacturing because of its connection to productivity and business profitability. Correspondingly reducing downtime in production processes, including Food and Manufacturing Groups (FMG's) have become a necessity since it also serves the purpose of maximizing machine uptime [1]. According to [2] Total productive maintenance (TPM) is defined as a maintenance program that involves concepts for maintaining plant and equipment effectively while OEE is a potent metric of manufacturing performance absorbing measures of the utilisation, yield and efficiency of a given process, machine or manufacturing line. The unit price of a product in the market is determined by the cost of all inputs into its production process. Equipment breakdown adds to the cost of production in form of downtime and repair costs. Being in control of machine accuracy, brought about by preventive maintenance (PM), will ensure machine tool availability, reduce the overall downtime in production, reduce waste, ensure quality of products and reduce running cost of maintenance activities [3]. This paper focuses on investigating the downtimes occurring in a fully automated production line comprising of nine (9) automated pneumatic packaging facilities shown in Figure 1, in the case study Nigerian multinational bottling company. These facilities are connected in series network and are inter-linked with each other by material handling system. Specifically, the filler system, described as "leading indicator" are tagged as vital, because its unavailability stops the production process.

Defined machine downtime [1] as off-the-time interval when machines are not operational for assigned duty. Machine downtime is one of the assignable causes of variation in a manufacturing system, resulting in poor production schedule reliability, it should be minimized, if not completely eliminated [4]. Hence, there is the need to access each bottling or packaging machinery and its sub-system with a holistic approach to establish an appropriate maintenance policy for an optimum Overall Equipment Efficiency (OEE) for production. Invariably, this will ensure nonperformance of excessive maintenance activities because the total maintenance costs of

\footnotetext{
* Corresponding author, email: okekola@oauife.edu.ng

(C) 2020 Alma Mater Publishing House
} 
machineries vary depending upon the type of work, complexity and age of the machine and all of these determine the unit cost of the product [5].

According to [6] downtime is any event that stops planned production for a period of time. Downtime categories are as follows: Planned downtime (PD) is the misplaced operating time due to planned events where there is no intention of keeping the plant operational, for example breaks, scheduled maintenance, and holidays. Plant operating time $(\mathrm{PO}(\mathrm{t}))$ is the total amount of time that the plant is available for operation. Planned production time $(\mathrm{PP}(\mathrm{t}))$ is the benchmark in which unplanned downtime events are measured against. Unplanned Downtime (UD) is the measures of the loss of planned production time due to unplanned events that cause downtime and affects OEE in a negative way, events such as operator's error, mechanical problems, and lack of oversight are some of the biggest varieties of reasons leading to unplanned downtime. Each of these events results when operations are shut down and each event time is added, hence the total amount of unplanned downtime is derived.

Plants availability is total unplanned downtime divided by planned production time.

According to [7], downtime tracking information is essential to precisely adjust the maintenance and operations management systems in order, to correct ongoing machinery deficiencies. Hence, there is the need to keep proper downtime record for chances that can help the plant in larger ways. Downtime record assists in arriving at an appropriate preventive maintenance or periodic maintenance rather than implementing corrective maintenance that will cost a lot of fortune each year in lost production. It is important to know what is causing the downtime and how to use this information to correct the problem. According to [7], keeping downtime record is the simplest of methods for tracking downtime where an operator simply fills-in a logbook noting downtime occurrences.

According to [8], the following five questions were raised and discussed to assist downtime reduction for the improvement of OEE; (i) What are the current method used in tracking or addressing downtime and OEE? (ii) Which plant, system, materials or employees have the greatest effect on downtime? (iii) How much downtime occurrence are not being recorded? (iv) How are downtime data currently analysed? and (v) What is the level of confidence when making decisions about increasing OEE efficiency? In his study, [8] provided some of the answers to the questions raised. According to him, addressing downtime problem requires proper understanding of what downtime is all about and the vital effect it has on OEE. The first step toward improving OEE is to reduce downtime by finding it. Root cause problem tool such as fish born, Five-why and DMAIC (i.e. Define, Measure, Analyze, Improve and Control) can serve as a useful tool. Employees that affect downtime include: Line Operators i.e. operators that are responsible for every cell on their assigned production line. A good line operator should be proactive in spotting problems before they happen invariably a bad line operator may be inattentive to his line, leaving downtime problems unresolved and unreported; Maintenance arcticians who must be proactive in fixing and maintaining all mechanical or electrical machine components according to work orders set up by the maintenance team. This will result in less machine-related downtime. An inexperienced Technician will only confront problems when they occur. They may fix the immediate problem, but no effort to curb downtime in the future which is important especially in plant where there could be hundreds if not thousands of machines or components running on a daily basis. Production or Shift Supervisor, he is instrumental in resolving issues causing downtime across the plant floor, keeps track and records of downtime and so many issues brought forth by his team members on the production plant floor. A proactive production supervisor spends his time addressing these issues with highest priority while delegating responsibility for the less important ones. On the other hand, an inexperienced production supervisor will simply run around from problem to problem but not setting priorities to solve the larger efficiency-related issues and not making efficient use of time. [8] concluded that a well-trained employee working toward a common goal is one of the biggest assets in an effort to increase OEE. Therefore, it is important to train these production employees on the need to decrease downtime, how it relates to the efficiency of the entire plant, the specific relevance of their role in the process and how they fit and contribute to the overall OEE strategy.

Sivaselvam and [9] emphasized the need and importance of proper data collection system in machine performance studies. According to them, most developing countries lack the norm of keeping production data and that hinders serious effort to improve machine performance using time series data. Any maintenance policy- preventive, predictive or corrective, towards reducing downtime continuously requires good information followed by appropriate action which involves frequent review and audit of manufacturing process aimed at detecting malfunctioning machine. However, it is completely clear that analysis of the resulting data is the basis for decisionmaking for the machine to be corrected [10]. 
PACKAGING LINE 7

V-CURVE

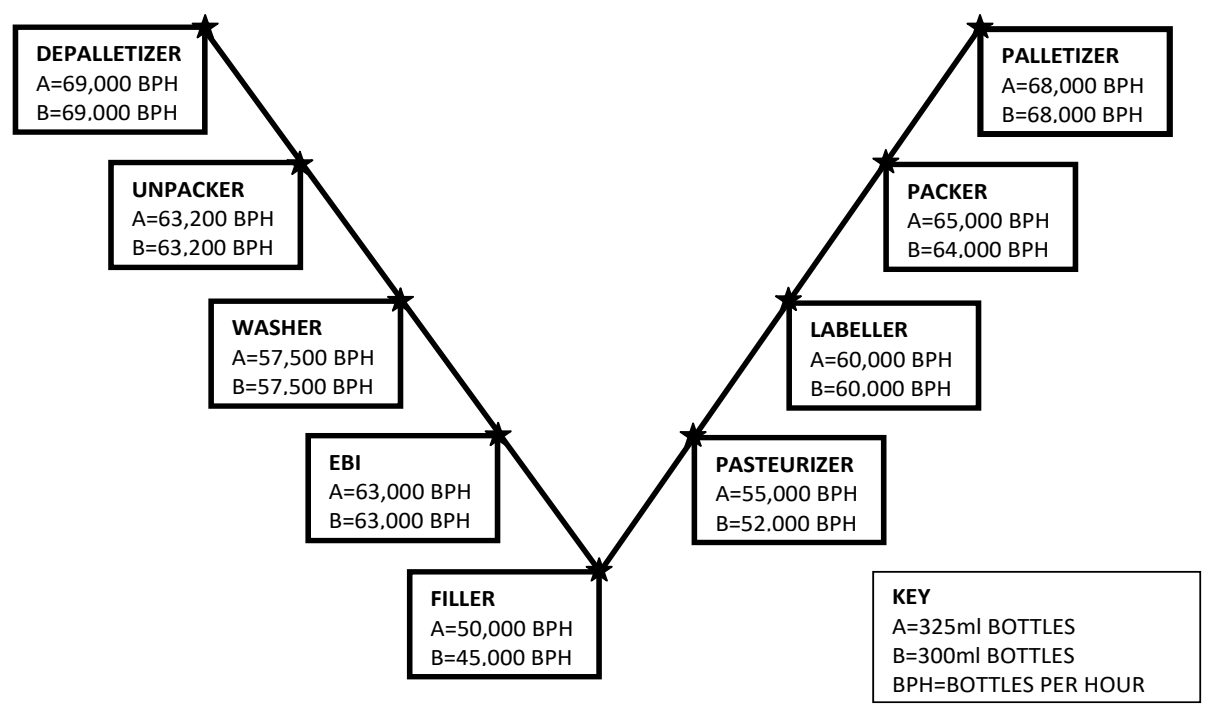

Fig. 1. Nine Bottling Packaging facilities.

\section{METHODOLOGY}

The basic steps that were employed for analyzing downtime for the Nigerian bottling company involve:

a) Gathering and Analysing Failure Data of Production Machines in the Nigerian Multinational Bottling Plant for a Period of Six Months. The raw data (Failure data) involved downtime and repair time for nine (9) packaging facilities mentioned above were analyzed.

b) Investigating and obtaining proper failure data. Failure data of these systems were recorded by all shift supervisors in a "report book" at the end of each shift for a period of one hundred and forty-six days (146 days) within six-months (Specifically from $16^{\text {th }}$ February, 2018 to $10^{\text {th }}$, July 2018). A sample of the report book recorded by shift supervisors is shown in Table 1 which involved downtime reports in minutes by operators with arcticians contributions on the nature and likelihood of equipment breakdown and repair time of the individual sub-systems that stopped production process. A semi-automatic data collecting system known as the human machine interface located at strategic locations on all the nine facilities proved useful in determining production targets and losses in terms of waste at the end of each shift run by operators and shift supervisors. A "Human Machine Interface" (HMI) automatically computes parameters used to calculate overall equipment efficiency (OEE) as shown in Figure 2 gives details on the number of hectoliter (HL) bottled at the end of the production process, these values are used as bench mark for comparison to ascertain key performance indicator (KPI) standards for the optimization of OEE. (HMI is an electronically programmed screen monitor used to control the operation of each facility by technical operators).

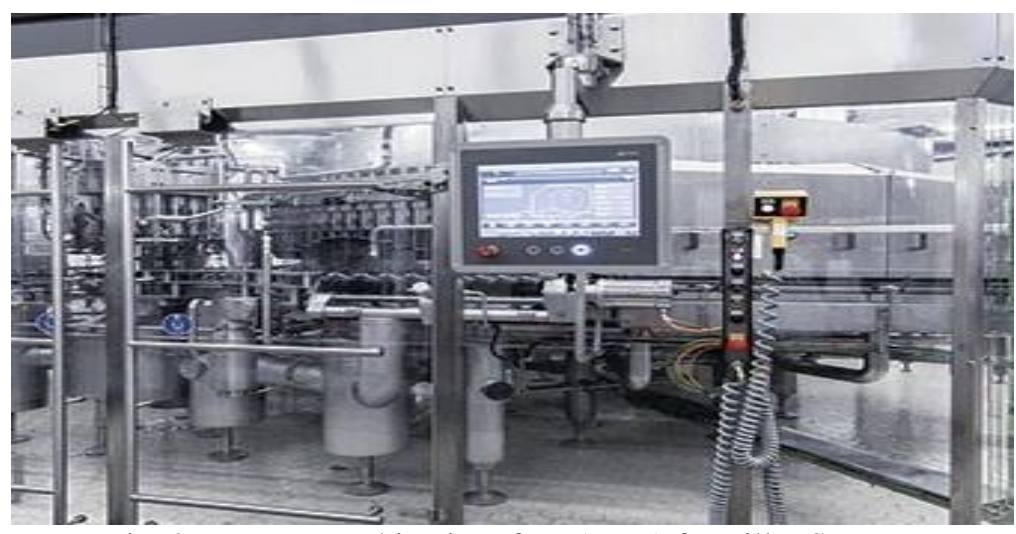

Fig. 2. Human Machine interface (HMI) for Filler System. 
Table 1. Sample of the downtime report book recorded by shift supervisors for the case study typical multinational bottling company.

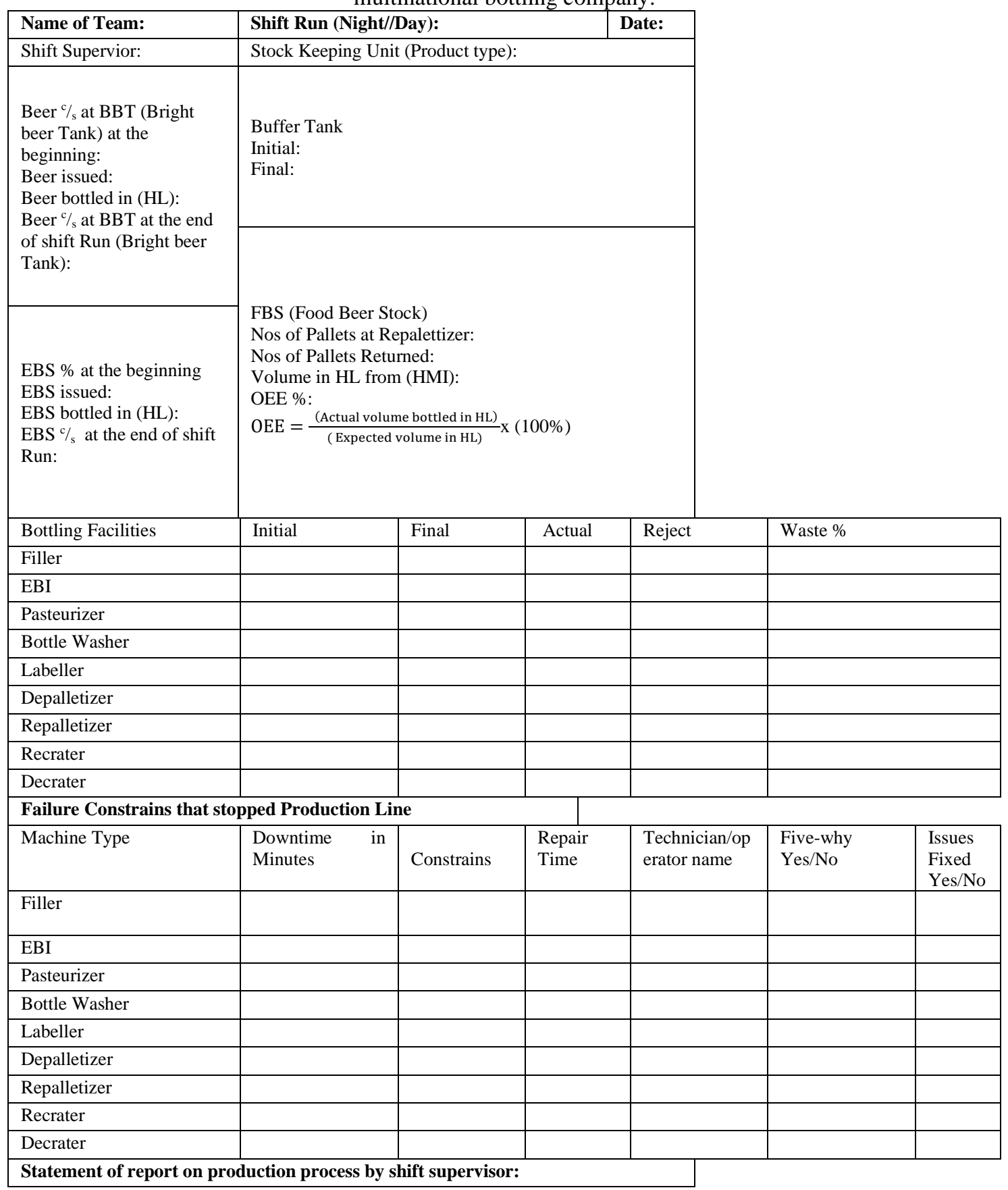

a) Ensuring specific and accurate downtime reports

Liaising with machine operators, and artisans experience was pivotal in getting accurate or specific downtime parameters. Liaising with shift supervisors, maintenance planner and installers' experience assisted in achieving some level of accuracy to ascertain specific downtime reports and the likelihood of failure occurrences of components on each of the nine facilities, this proved vital in classifying failures with the greatest contributor to downtime and its involvement in the Six-Sigma process. Censored observations and uncensored observation (complete failure times) were taken into consideration. Censored observation also known as incomplete failure/responses in this study describes the probability that not all items or components of the packaging systems or facilities in the production process will fail at the end of the specific loading or operational time (observed failure time or experiment). Uncensored observation signifies the complete responses (frequency of failure occurrences). 
b) Stratification of the failure or downtime data obtained

Data stratification simply entails the separation of data into smaller, more defined form based on a predetermined set of criteria such as planned and unplanned downtime events bearing in mind censored and uncensored observations. Table 2 identifies the classification of failure data into planned and unplanned downtime events in which the six-month duration period at 146 days was narrowed down to five months of 126 days; the first four months comprised of 28 days for each month, while 14 days represented the fifth month. Most times interpreting failure data can be overwhelming, therefore breaking down these failure data into smaller and reliable bits of information makes the collected data easier to understood. Stratified failure data for nine facilities are shown in Tables 3 to 11 .

Table 2. Stratification of planned and unplanned downtime activities from the failure data obtained.

\begin{tabular}{|c|c|c|c|}
\hline \multicolumn{4}{|l|}{ Unplanned Downtime Activities } \\
\hline One/ First Month Represents: & \multicolumn{3}{|c|}{ February (28 days), 2018.} \\
\hline Second Month Represents: & \multicolumn{3}{|c|}{ March for (28 days), 2018.} \\
\hline Third Month Represents: & \multicolumn{3}{|c|}{ April (28 days), 2018.} \\
\hline Fourth Month Represents: & \multicolumn{3}{|c|}{ May (28 days), 2018.} \\
\hline Fifth Month Represents: & \multicolumn{3}{|c|}{ June (14 days), 2018.} \\
\hline \multicolumn{4}{|l|}{ Planned Downtime Activities } \\
\hline \multicolumn{4}{|c|}{ Six Month: is classified under planned downtime activities. These activities are stated below. } \\
\hline Activities & Dates & month & Year \\
\hline General Maintenance & $17^{\text {th }}$ to $23^{\text {rd }}$ & June & 2018 \\
\hline Stock count & $30^{\text {th }}$ and $31^{\text {st }}$ & March & 2018 \\
\hline Fumigation of packaging plant & $2^{\text {nd }}$ to $8^{\text {th }}$ & June & 2018 \\
\hline
\end{tabular}

\section{RESULTS AND DISCUSSION}

a) Input Failure Data for Downtime Analysis

There are nine facilities in which downtime losses were recorded by the production department during the time of machine operation for one hundred and twenty-six- days (126 days) with loading time of 3024 hours. All downtime analysis (Pareto chart analysis, Weibull Distributions and Reliability/Failure Time Analysis) were carried out based on the above stated conditions.

Tables 3 to 11 identifies the stratified failure data obtained from (9) nine packaging facilities in the case study Nigerian multinational bottling company

Table 3. Stratified failure data for Filler machine.

\begin{tabular}{|l|l|c|c|c|c|}
\hline $\begin{array}{c}\text { Failure } \\
\text { codes }\end{array}$ & Failure description/Constrains (Defect) & $\begin{array}{c}\text { Downtime in } \\
\text { Minutes } \\
(\mathrm{X})\end{array}$ & $\begin{array}{c}\text { Frequency } \\
(\text { Counts) } \\
(\mathrm{Y} / \mathrm{N})\end{array}$ & $\begin{array}{c}\text { Cumulative } \\
\text { Downtime } \\
(\mathrm{X} / \mathrm{Y})\end{array}$ & $\begin{array}{c}\text { Year of } \\
\text { installation }\end{array}$ \\
\hline $\mathrm{F}_{\mathrm{a}}$ & Active capper malfunction (flow control) & 1198 & $51 / 126$ & 23 & 2011 \\
\hline $\mathrm{F}_{\mathrm{b}}$ & In feed worm altered. & 466 & $12 / 126$ & 39 & 2011 \\
\hline $\mathrm{F}_{\mathrm{c}}$ & (Speed loss) Bottle conveyor fault & 766 & $22 / 126$ & 35 & 2011 \\
\hline Others & $\begin{array}{l}\text { Change over at filler cleaning in progress } \\
\text { (CIP). CIP in Progress. Filler Startup. } \\
\text { Removal of CIP Cups, fine tuning }\end{array}$ & 2125 & $27 / 126$ & 79 & 2011 \\
\hline $\mathrm{F}_{\mathrm{l}}$ & Correction of low fills & 527 & $10 / 126$ & 53 & 2011 \\
\hline $\mathrm{F}_{\mathrm{e}}$ & $\begin{array}{l}\text { Frequent Synchronization error fault } \\
\text { (Speed loss) }\end{array}$ & 520 & $12 / 126$ & 43 & 2011 \\
\hline $\mathrm{F}_{\mathrm{s}}$ & $\begin{array}{l}\text { Filler swabbing. Speed loss due to high } \\
\text { beer temperature }\end{array}$ & 69 & $2 / 126$ & 35 & 2011 \\
\hline $\mathrm{F}_{\mathrm{w}}$ & Not operating due to low lift cylinder & 30 & $2 / 126$ & 15 & 2011 \\
\hline $\mathrm{F}_{\mathrm{e}}$ & $\begin{array}{l}\text { Speed loss to frequent filler } \\
\text { synchronization error. Work done on filler } \\
\text { synchronization error }\end{array}$ & 130 & $2 / 126$ & 65 & 2011 \\
\hline $\mathrm{F}_{\mathrm{h}}$ & HMI temperature crashing & 92 & $4 / 126$ & 23 & 2011 \\
\hline $\mathrm{F}_{\mathrm{s}}$ & CIP, swabbing of filler & 689 & $13 / 126$ & 53 & 2011 \\
\hline $\mathrm{F}_{\mathrm{p}}$ & Filler HPI worked on & 120 & $1 / 126$ & 120 & 2011 \\
\hline
\end{tabular}


Table 4. Stratified Failure data for Labeller Machine and sub-system.

\begin{tabular}{|l|l|c|c|c|c|}
\hline $\begin{array}{c}\text { Failure } \\
\text { codes }\end{array}$ & Failure description/Constrains & $\begin{array}{c}\text { Downtime } \\
\text { in Minutes }\end{array}$ & Frequency & $\begin{array}{c}\text { Cumulative } \\
\text { Downtime }\end{array}$ & $\begin{array}{c}\text { Year of } \\
\text { installation }\end{array}$ \\
\hline $\mathrm{La}$ & Fine tuning of gripper cylinder & 873 & $8 / 126$ & 109 & 2011 \\
\hline $\mathrm{Lb}$ & $\begin{array}{l}\text { Speed loss; missing body label or flagging of neck } \\
\text { label/missing label causing backup at filler. }\end{array}$ & 2055 & $41 / 126$ & 50 & 2011 \\
\hline Others & Change over to export label. Changeover for export labels & 152 & $2 / 126$ & 25 & 2011 \\
\hline $\mathrm{Lv}$ & Labeller 7B Videojet failed. & 680 & $17 / 126$ & 40 & 2011 \\
\hline $\mathrm{Lc}$ & $\begin{array}{l}\text { Bottle Conveyor fault; Discharge conveyor 7TB36 } \\
\text { derailed due to faulty motor drive operating }\end{array}$ & 443 & $12 / 126$ & 37 & 2011 \\
\hline $\mathrm{Lg}$ & Replacement of labeler 7B worn out centering bell & 32 & $1 / 126$ & 32 & 2011 \\
\hline $\mathrm{Lf}$ & Safety stop button faulty & 43 & $2 / 126$ & 22 & 2011 \\
\hline
\end{tabular}

Table 5. Stratified Failure data for Bottle Washer Machine and sub-system.

\begin{tabular}{|c|c|c|c|c|c|}
\hline $\begin{array}{c}\text { Failure } \\
\text { codes }\end{array}$ & Failure description/Constrains & $\begin{array}{l}\text { Downtime in } \\
\text { Minutes }\end{array}$ & Frequency & $\begin{array}{l}\text { Cumulative } \\
\text { Downtime }\end{array}$ & $\begin{array}{l}\text { Year of } \\
\text { installation }\end{array}$ \\
\hline $\mathrm{Ba}$ & $\begin{array}{l}\text { Washer soak } 1,2 \text { or soak } 3 \text { Mat faulty (fine-tuning of } \\
\text { components causing poor label extraction). }\end{array}$ & 563 & $6 / 126$ & 94 & 2011 \\
\hline $\mathrm{Bb}$ & $\begin{array}{l}\text { Speed loss due to label carry over; as a result of (Bad } \\
\text { bottles/insufficient caustic) at infeed or discharge. } \\
\text { Bottle Jam due to label carryover. Speed loss to bottle } \\
\text { due to caustic (2) level crashing } \\
\text { Speed loss due to bottle washer chain } 1 \text { trailing error } \\
\text { faulty }\end{array}$ & 461 & $13 / 126$ & 36 & 2011 \\
\hline Others & $\begin{array}{l}\text { CIP/Start up, Start up and loading of bottles in } \\
\text { washer }\end{array}$ & 583 & $11 / 126$ & 53 & 2011 \\
\hline $\mathrm{Bf}$ & Frequent I- drive fault (zero -position not reached) & 761 & $13 / 126$ & 59 & 2011 \\
\hline $\mathrm{Bc}$ & $\begin{array}{l}\text { Conveyor fault leading to speed loss. Massive falling } \\
\text { bottles at discharge. Massive fallen bottles at } \\
\text { discharge. Massive fallen bottles due to twisted } \\
\text { discharge conveyor }\end{array}$ & 996 & $21 / 126$ & 47 & 2011 \\
\hline $\mathrm{Bd}$ & $\begin{array}{l}\text { Dumping of final rinse water Bottle washer with } \\
\text { CLIT in progress. Dumping of final rinse. Removal } \\
\text { and poking of final rinse spray bar }\end{array}$ & 404 & $12 / 126$ & 34 & 2011 \\
\hline $\mathrm{Bh}$ & $\begin{array}{l}\text { Bottle washer HMI screen hanged. Bottle washer } \\
\text { HMI screen hanged }\end{array}$ & 88 & $5 / 126$ & 18 & 2011 \\
\hline $\mathrm{Bw}$ & Vibrator finger spines sheared off (WIP) & 88 & $2 / 126$ & 44 & 2011 \\
\hline \multirow[t]{2}{*}{$\mathrm{Bx}$} & Comart scuffex closing pump failed & 25 & $1 / 126$ & 25 & 2011 \\
\hline & Date $17 / 06 / 2018$ to $23 / 06 / 2018$. General Maintenance & & & & \\
\hline
\end{tabular}

Table 6. Stratified failure data for Pasteurizer machine and sub-system.

\begin{tabular}{|c|c|c|c|c|c|}
\hline $\begin{array}{l}\text { Failure } \\
\text { codes }\end{array}$ & $\begin{array}{l}\text { Failure description/ } \\
\text { Constrains }\end{array}$ & $\begin{array}{l}\text { Downtime in } \\
\text { Minutes }\end{array}$ & Frequency & $\begin{array}{l}\text { Cumulative } \\
\text { Downtime }\end{array}$ & $\begin{array}{c}\text { Year of } \\
\text { installation }\end{array}$ \\
\hline $\mathrm{Pa}$ & $\begin{array}{l}\text { Bottle conveyor fault (causing massive fallen } \\
\text { bottles/excessive glass breakages at infeed or } \\
\text { discharge. Derailment of pasteurizer discharge } \\
\text { conveyor. Bad conveyor guide. Conveyor Asi fault } \\
\text { (electrical malfunction). }\end{array}$ & 1428 & $38 / 126$ & 38 & 2011 \\
\hline others & $\begin{array}{l}\text { Machine not functional due to power outage utility } \\
\text { department }\end{array}$ & 35 & $1 / 126$ & 35 & 2011 \\
\hline $\mathrm{Pe}$ & $\begin{array}{l}\text { Malfunction of Emergency stop button at Passy } \\
\text { discharge }\end{array}$ & 55 & $3 / 126$ & 15 & 2011 \\
\hline $\mathrm{Px}$ & $\begin{array}{l}\text { Excessive glass breakage at Passy discharge due to } \\
\text { thermal shock }\end{array}$ & 65 & $1 / 28$ & 65 & 2011 \\
\hline
\end{tabular}

b) Pareto chart analysis for nine packaging systems in a production line

Table 12 showed that a total of nine (9) systems efficiency was at $100 \%$ as at the last maintenance practice carried out by the company, but as the facilities undergo continuous operation within a specified load time at 3024 hours as shown, failure occurrences (represented as counts) disrupts the optimal efficiency of systems operation. The critical point of systems reliability and efficiency at (70\%) identifies and distinguishes facilities with highest and lowest percentage of downtime (Nicolas and Rosemary, 2006). Filler, EBI, Labeller and Bottle Washer (BW) designates unreliability having the highest percentage of downtimes while the remaining facilities or systems signifies reliability. 
Table 7. Stratified Failure data for Empty Bottle Inspector Machine and sub-system.

\begin{tabular}{|l|l|c|c|c|c|}
\hline $\begin{array}{c}\text { Failure } \\
\text { codes }\end{array}$ & $\begin{array}{l}\text { Failure description/ } \\
\text { Constrains }\end{array}$ & $\begin{array}{c}\text { Downtime in } \\
\text { Minutes }\end{array}$ & Frequency & $\begin{array}{c}\text { Cumulative } \\
\text { Downtime }\end{array}$ & $\begin{array}{c}\text { Year of } \\
\text { installation }\end{array}$ \\
\hline Ea & $\begin{array}{l}\text { Speed loss due to conveyor fault; Excessive bottle } \\
\text { jam/rejection, glass jam at Infeed/discharge; Excessive } \\
\text { rejection of bottles due to chip neck. Bottle conveyor fault; Jam } \\
\text { at EBI due to continuous rejection on base/inner side walls. } \\
\text { Glass jam at EBI in feed. Bottle Jam at both in feed and } \\
\text { discharge (conveyor and side walls/guide adjustment). }\end{array}$ & 3150 & $89 / 126$ & 35 & 2011 \\
\hline Others & Start up in progress for New SKU (Stock keeping unit) & 220 & $4 / 126$ & 55 & 2011 \\
\hline Eph & HMI hanged & 255 & $7 / 126$ & 34 & 2011 \\
\hline Ex & $\begin{array}{l}\text { False rejection of bottles due to Exceeding time to switch gear } \\
\text { fault. False glass rejection. Glass jam. Glass jam }\end{array}$ & 412 & $10 / 126$ & 41 & 2011 \\
\hline
\end{tabular}

Table 8. Stratified failure data for Repalletizer machine and sub-system.

\begin{tabular}{|l|l|c|c|c|c|}
\hline $\begin{array}{l}\text { Failure } \\
\text { Codes }\end{array}$ & $\begin{array}{l}\text { Failure description/ } \\
\text { Constrains }\end{array}$ & $\begin{array}{c}\text { Downtime in } \\
\text { Minutes }\end{array}$ & Frequency & $\begin{array}{c}\text { Cumulative } \\
\text { Downtime }\end{array}$ & $\begin{array}{c}\text { Year of } \\
\text { installation }\end{array}$ \\
\hline Zf & Frequency inverter (electrical fault) & 98 & $7 / 126$ & 13 & 2011 \\
\hline $\mathrm{Zm}$ & $\begin{array}{l}\text { Crate miscount, Rubberized chains worn out (speed loss). } \\
\text { Crate miscount at infeed. Crate miscount (infeed conveyor) }\end{array}$ & 185 & $15 / 126$ & 12 & 2011 \\
\hline $\mathrm{Za}$ & Crate Jam at divider; misalignment of the roller shafts & 416 & $12 / 126$ & 35 & 2011 \\
\hline others & Power Outage & 35 & $1 / 126$ & 35 & 2011 \\
\hline $\mathrm{Zc}$ & Overhead crate conveyor at discharge to repal derailed & 376 & $11 / 126$ & 34 & 2011 \\
\hline $\mathrm{Zs}$ & Compressed air monitoring fault at repal & 45 & $1 / 126$ & 45 & 2011 \\
\hline $\mathrm{Zh}$ & Carrier head Table “1' Hook and close 62B28 malfunction & 141 & $5 / 126$ & 28 & 2011 \\
\hline $\mathrm{Zp}$ & $\begin{array}{l}\text { Work on repal pallet roller drive chain. Work on repal in } \\
\text { feed conveyor }\end{array}$ & 60 & $2 / 126$ & 30 & 2011 \\
\hline
\end{tabular}

Table 9. Stratified Failure data for Depalletizer Machine and sub-system.

\begin{tabular}{|l|l|c|c|c|c|}
\hline $\begin{array}{l}\text { Failure } \\
\text { codes }\end{array}$ & $\begin{array}{l}\text { Failure description/ } \\
\text { Constrains }\end{array}$ & $\begin{array}{c}\text { Downtime in } \\
\text { Minutes }\end{array}$ & Frequency & $\begin{array}{c}\text { Cumulative } \\
\text { Downtime }\end{array}$ & $\begin{array}{c}\text { Year of } \\
\text { installation }\end{array}$ \\
\hline Ya & $\begin{array}{l}\text { Pallet Roller malf. Electronic fault. Electronic sensor } \\
\text { misalignment intermittently }\end{array}$ & 270 & $10 / 126$ & 27 & 2011 \\
\hline Yc & $\begin{array}{l}\text { Discharge overhead conveyor derailed (7TR 32). Discharge } \\
\text { tapered rollers drive chain cut. Conveyor discharge photocell } \\
\text { misaligned }\end{array}$ & 228 & $10 / 126$ & 23 & 2011 \\
\hline Yh & Carrier head malf. Carrier head malf. Head dropping crates & 192 & $7 / 126$ & 27 & 2011 \\
\hline Ye & Light Safety barrier malfunctioned & 45 & $2 / 126$ & 23 & 2011 \\
\hline Yp & Depal pallet stopper work loosed. & 26 & $1 / 126$ & 26 & 2011 \\
\hline Others & Line cut-off from depal/running out in progress & 80 & $2 / 126$ & 35 & 2011 \\
\hline
\end{tabular}

Table 10. Stratified Failure data for Recrater machine and sub-system.

\begin{tabular}{|l|l|c|c|c|c|}
\hline $\begin{array}{l}\text { Failure } \\
\text { codes }\end{array}$ & $\begin{array}{l}\text { Failure description/ } \\
\text { Constrains }\end{array}$ & $\begin{array}{c}\text { Downtime in } \\
\text { Minutes }\end{array}$ & $\begin{array}{l}\text { Frequency } \\
\text { Ra }\end{array}$ & $\begin{array}{l}\text { Cumulative } \\
\text { Downtime }\end{array}$ & $\begin{array}{c}\text { Year of } \\
\text { installation }\end{array}$ \\
\hline $\begin{array}{l}\text { mascount causing speed loss. In feed bottle conveyor derailed } \\
\text { zone conveyor (derailment), no lubrication. Packing zone drive } \\
\text { sprocket worn out, replaced (work in progress). Discharge } \\
\text { stopper work-loosed. Changing of wear-strip and slat chain at } \\
\text { packing zone. Frequent crate jam at packing zone due to bad } \\
\text { conveyor. Worked on discharge stopper }\end{array}$ & 573 & $22 / 126$ & 22 & 2011 \\
\hline $\mathrm{Rb}$ & $\begin{array}{l}\text { Bottle/ Table conveyor derailment at infeed/discharge. Excess } \\
\text { bottle burst/Massive fallen bottles at infeed Table conveyor } \\
\text { /bottle station }\end{array}$ & 221 & $11 / 126$ & 20 & 2011 \\
\hline $\mathrm{Rc}$ & $\begin{array}{l}\text { Crate guide misaligned. Rollers at crate turner misaligned. } \\
\text { Shaft sheared off. Bad sprocket. Discharge crate guide } \\
\text { misaligned. Rollers at crate turner sheared off }\end{array}$ & 60 & $4 / 14$ & 15 & 2011 \\
\hline $\mathrm{Rh}$ & $\begin{array}{l}\text { Carrier head malf. Excessive dropping of bottles from tulips } \\
\text { causing speed loss. Air leakage from air hose/busted cub }\end{array}$ & 100 & $12 / 126$ & 8 & 2011 \\
\hline Others & $\begin{array}{l}\text { Change over } \\
\text { Power outage by Utility }\end{array}$ & 108 & $2 / 126$ & 126 & 2011 \\
\hline
\end{tabular}


Table 11. Stratified Failure data for Decrater machine and sub-system.

\begin{tabular}{|c|c|c|c|c|c|}
\hline $\begin{array}{l}\text { Failure } \\
\text { codes }\end{array}$ & $\begin{array}{l}\text { Failure description/ } \\
\text { Constrains }\end{array}$ & $\begin{array}{c}\text { Downtime in } \\
\text { Minutes }\end{array}$ & Frequency & $\begin{array}{l}\text { Cumulative } \\
\text { Downtime }\end{array}$ & $\begin{array}{c}\text { Year of } \\
\text { installation }\end{array}$ \\
\hline $\mathrm{Da}$ & $\begin{array}{l}\text { Speed loss. Crates at packing zone not aligned miss count } \\
\text { (crate guides at packing zone not aligned). Conveyor fault } \\
\text { causing speed loss. Decrater in feed photocell (sensor) at } \\
\text { packing zone faulty }\end{array}$ & 61 & $4 / 126$ & 15 & 2011 \\
\hline $\mathrm{DCa}$ & $\begin{array}{l}\text { Conveyor derailment. overhead conveyor discharge of } \\
\text { decrater at crate washer. Crate hook intermittently at } \\
\text { infeed/discharge due to crate guide misalignment }\end{array}$ & 154 & $18 / 28$ & 9 & 2011 \\
\hline Dr & Carrier head not referencing & 60 & $1 / 126$ & 60 & 2011 \\
\hline Dc & $\begin{array}{l}\text { In feed discharge stopper malf, discharged overhead } \\
\text { conveyor roller collapsed. Crate conveyor to infeed } \\
\text { Decrater derailed. Due to lack of lubrication. Discharge } \\
\text { Overhead conveyor to crate washer faulty. Roller drive } \\
\text { chain cut. Rollers sheared off }\end{array}$ & 442 & $19 / 126$ & 23 & 2011 \\
\hline Others & $\begin{array}{l}\text { Change over } \\
\text { Power outage by Utility }\end{array}$ & 138 & $3 / 126$ & 46 & 2011 \\
\hline
\end{tabular}

Table 12. Input data spreadsheet for the Pareto chart analysis for all nine facilities.

\begin{tabular}{|l|l|l|l|}
\hline Month & $\begin{array}{l}\text { Loading Time } \\
\text { (hrs) }\end{array}$ & Defect (List of variable types) & $\begin{array}{l}\text { Count (variable list of failure } \\
\text { count) }\end{array}$ \\
\hline Five months & 3024 & Filler & 159 \\
\hline Five months & 3024 & EBI & 102 \\
\hline Five months & 3024 & Labeller & 86 \\
\hline Five months & 3024 & Bottle washer & 84 \\
\hline Five months & 3024 & Recrater & 55 \\
\hline Five months & 3024 & Repalletizer & 54 \\
\hline Five months & 3024 & Decrater & 49 \\
\hline Five months & 3024 & Pasteurizer & 43 \\
\hline Five months & 3024 & Depalletizer & 32 \\
\hline
\end{tabular}

\section{CONCLUSIONS}

In order, to increase the uptime of equipment or machinery in a bottling plant, knowledge of the failure mode of equipment and its reliability is essential. This study was limited to nine bottling facilities such as Filler, Labeler, Bottle Washer, Pasteurizer, Empty Bottle Inspector (EBI), Depallletizer, Repalletizer, Recrater and Decrater. After obtaining proper downtime information, stratification of failure data was conducted to achieve accurate and specific downtime information for reliability/failure analysis.

It was observed that the lowest level of reliability due to high number of failure occurrences was associated with Filler, EBI, Labeler, Bottle Washer, Recrater, Repalletizer, Decrater, Pasteurizer and Depalletizer as shown in Table 12. Filler machine is the "life wire" or "leading indicator" when compared to the other eight packaging systems connected in series in the bottling production plant, consequently a continuous production process of the remaining eight facilities are dependent on the operational efficiency of Filler machine. Correspondingly, the case is the same for most brewery or bottling plant worldwide because, there is usually no alternative use when the Filler system is not operational.

Due to the critical unreliability of Filler machine, installation of a standby Filler system is the only way out in situations where target is high in production. Benefit of a standby Filler will ensure that maintenance work one Filler system will not result in total shutdown of the whole production unit. Therefore, serious caution on Filler machine must be taken to ensure optimal operation of nine facilities involved in the production process. Maintenance workshop seminars must be organized on a monthly scale for all skilled and unskilled operators, arcticians, maintenance engineers, supervisors to improve their skills and knowledge on tracking downtime to minimize production losses. 


\section{REFERENCES}

[1] Nwanya, J.I., Udofia, Ajayi, O.O., Optimization of machine downtime in the plastic manufacturing, Cogent Engineering, vol. 4, no. 1, 2017 p. 1-12.

[2] Shagluf, A., Longstaff, A.P., Fletcher, S., Maintenance strategies to reduce downtime due to machine Positional errors, Maintenance Performance Measurement and Management Conference Coimbra, Portugal, 2014.

[3] Battini, D., Manzini, R., Persona, A., Regattieri, A., TPL approach and new buffer design paradigm in plant layout, 12th ISSAT Iternational Conference on Reliability and Quality Design, Chicago, August 3-5, 2006.

[4] Nwanya, S.C., Achebe, C.N., Ajayi, O.O., Mgbemene, C.N., Process variability analysis in make-to-order production systems, Cogent Engineering, vol. 3, 2016, 1-14.

[5] Löfsten, H., Measuring maintenance performance in search for a maintenance productivity index, International Journal of Production Economics, vol. 63, 2000, p. 47-58.

[6] Hechtman, T., How to reduce downtime and raise overall equipment efficiency? Folsom, CA: Inductive Automation, 2011.

[7] George, M., Up-time and how to reduce downtime. Downtime measuring and reduction, Evergreen engineering Inc, 2006.

[8] Hechtman, T., Making OEE implementations a success, Folsom, CA Inductive Automation, 2016.

[9] Sivaselvam, E., Gajendran, S., Improvement of overall equipment effectiveness in a plastic injection moulding industry, Journal of Mechanical and Civil Engineering, vol. 5, 2014, p. 12-16.

[10] Shagluf, A., Longstaff, A.P., Fletcher, S., Denton., P.D., Downtime cost function to optimise machine tool calibration schedules, International Conference on Advanced Manufacturing Engineering and Technologies, KTH Royal Institute of Technology in Stockholm, Sweden, 2013. 